\title{
A CHEFIA XINGUANA E SUAS CASAS
}

\author{
Antonio Roberto Guerreiro Júnior"
}

RESUMO: De tempos em tempos, os Kalapalo e demais alto-xinguanos constroem estruturas especiais para seus chefes: grandes casas decoradas para chefes vivos, e sepulturas especiais para nobres falecidos - também concebidas como suas "casas". Neste artigo analiso como estas estruturas guardam uma série de analogias com o modelo de corpo dos chefes, procurando mostrar como casas, sepulturas e corpos nobres objetivam, em diferentes escalas, uma dualidade entre humanidade/consanguinidade e animalidade/ afinidade. A partir de um diálogo com as formulações de Lévi-Strauss sobre a Casa, argumento que a chefia xinguana é caracterizada pela síntese de princípios de unidade e antagonismo, cuja objetivação é parte necessária do movimento pelo qual os grupos xinguanos se diferenciam e se identificam no sistema regional, oferecendo as bases do processo do parentesco.

PALAVRAS-CHAVE: Casa, chefia, parentesco, Alto Xingu, Kalapalo.

\footnotetext{
* Este artigo condensa alguns argumentos desenvolvidos em minha tese de doutorado, defendida junto ao Programa de Pós-Graduação em Antropologia Social da Universidade de Brasília (Guerreiro Júnior, 2012). Agradeço a Marcos Lanna por ter me incentivado, há muito tempo, a abordar a questão das "Casas" no Alto Xingu. Também agradeço a Marcela Coelho de Souza, cujas interpretações sobre o conceito de Casa foram decisivas para a elaboração de meu argumento. Os pareceristas anônimos deste trabalho também fizeram comentários muito enriquecedores, que espero ter conseguido incorporar ao texto. As incorreções, imprecisões e exageros são, claro, de minha inteira responsabilidade. Professor do Departamento de Antropologia e do Programa de Pós-Graduação em Antropologia Social da Universidade Estadual de Campinas (Unicamp).
} 


\section{INTRODUÇÃO}

Em diferentes ocasiões, os alto-xinguanos constroem casas especiais para seus chefes (anetüi ${ }^{1}$ em kalapalo). Algumas são, de fato, habitações (chamadas talïhe); outras, porém, são túmulos (chamados tahiti), concebidos como as "casas dos mortos". E ambas são, igualmente, corpos, guardando diversas analogias com o corpo humano em geral e, especificamente, com seu arquétipo, o corpo dos chefes. Tendo isso em consideração, não parece exagero dizer que estas casas especiais, sejam túmulos ou habitações, são atualizações particulares de traços corporais que constituem a condição de chefia. Trata-se de "formas-chefe", isto é, formas substancializadas, objetivadas, de atributos típicos da chefia. E, se essas "casas" são pensadas como corpos, análogos aos dos chefes de carne e osso, não seria impossível questionar se a própria chefia, por sua vez, não poderia ser pensada a partir dos atributos de tais "casas".

O objetivo deste artigo é discutir algumas relações entre casa, corpo e pessoa na chefia xinguana, a partir de uma pesquisa de campo desenvolvida entre os Kalapalo, falantes de uma variante da língua karib do Alto Xingu². Argumento que as "casas" mencionadas acima evocam uma das últimas transformações do conceito de Casa de Lévi-Strauss que aparecem em Minhas

\footnotetext{
${ }^{1}$ Toda aldeia xinguana possui pelo menos um homem considerado anetii (além de mulheres "chefas", itankgo). A chefia é uma condição corporal reproduzida de geração em geração, criando uma imagem de "hereditariedade", mas que não implica necessariamente "poder", e sim a ocupação de certas posições no sistema de rituais regionais, como dono (patrocinador), homenageado ou coordenador. A necessidade de fabricação de chefes a cada geração cria "famílias nobres", que ocupam posições de prestígio em um esquema hierárquico instável. Se essa hierarquia implica ou não alguma forma de poder coercitivo ou simbólico, é um debate ainda em aberto (Barcelos Neto, 2008; Figueiredo, 2006, 2010; Guerreiro Júnior, 2012; Heckenberger, 2005) e bastante marcado por concepções euro-americanas da política (ver Guerreiro Júnior, 2011b).

${ }^{2}$ O Alto Xingu é um complexo multiétnico e multilíngue localizado na porção sul do Parque Indígena do Xingu (MT). Dele fazem parte dez povos pertencentes a três dos principais agrupamentos linguísticos sul-americanos, além de falantes de uma língua considerada isolada. São eles os Mehinaku, Wauja e Yawalapíti (falantes de línguas arawak); os Kalapalo, Nahukwa, Kuikuro e Matipu (falantes de karib); Kamayurá e Aweti (tupi); e os Trumai (língua isolada).
} 
Palavras (Lévi-Strauss, 1986), segundo a qual a Casa deixa de ser definida como uma "pessoal moral" (visão ainda aparentada ao conceito de "grupo corporado") e passa a ser vista como a objetivação de relações antagônicas. Nos casos examinados por Lévi-Strauss, tratava-se de antagonismos inerentes à afinidade efetiva, como a oposição entre doadores e tomadores de esposas; no caso kalapalo e, possivelmente, alto-xinguano em geral, argumento que a chefia é constituída por um antagonismo entre consanguinidade e afinidade potencial, cuja objetivação sob a forma de corpos-casas é parte necessária do movimento pelo qual os grupos xinguanos se diferenciam e se identificam no sistema regional, oferecendo as bases do processo do parentesco.

\section{O CONCEITO DE CASA E A ETNOLOGIA AMERICANISTA}

O conceito de "sociedades de casas" (societés à maisons) surge tardiamente na obra de Lévi-Strauss, como uma tentativa de preencher uma lacuna em sua teoria do parentesco: os sistemas cognáticos ou de filiação indiferenciada (LéviStrauss, 2004). Lévi-Strauss parte das descrições de Franz Boas sobre o numaym (ou numayma) entre os Kwakiutl da América do Norte, e da dificuldade para caracterizar esse tipo de grupo. O material etnográfico indicava a coexistência de princípios antagônicos de pertencimento aos numaym, como filiação patri e matrilinear, o que dificultava sua identificação aos tipos de grupos tradicionalmente descritos pela antropologia:

(...) esse tipo de instituição não corresponde a nenhum dos três modos de descendência - unilinear, bilinear, indiferenciada - que se tende a tratar como categorias separadas, enquanto as instituições de tipo numayma os sobrepõem³. (Lévi-Strauss, 2004, p. 148)

\footnotetext{
${ }^{3}$ A fim de colaborar para a fluidez do texto, todas as citações diretas em línguas estrangeiras foram traduzidas para o português.
} 
A coexistência de diferentes regras de pertencimento por descendência se combinaria ainda com a possibilidade de entrada em um numaym por aliança: um homem casado passaria a fazer parte do numaym de seu sogro. Esse tipo de instituição também seria caracterizado pela posse de riquezas materiais e imateriais, como nomes, cantos, títulos, prerrogativas rituais, e se reproduziria por meio de sua transmissão. Como tanto a consanguinidade quanto a afinidade poderiam servir à transmissão de tais propriedades, o parentesco ficaria sujeito à subversão por interesses políticos e econômicos, pois as pessoas poderiam "travestir todo o tipo de manobras sociopolíticas sob a roupagem do parentesco" (ibid., p. 149). É importante notar que, para Lévi-Strauss, a existência de tais "interesses políticos e econômicos" seria característica de sociedades hierárquicas, como os Kwakiutl. Em vista disso, Lévi-Strauss propõe uma analogia entre esses agrupamentos e as Casas nobres da Europa Medieval, apresentando sua definição clássica da Casa como uma

(...) pessoa moral detentora de um domínio composto ao mesmo tempo de bens materiais e imateriais, que se perpetua pela transmissão de seu nome, de sua fortuna e de seus títulos em linha real ou fictícia, considerada legítima com a única condição de que essa continuidade possa se exprimir pela linguagem do parentesco ou da aliança, e, mais frequentemente, das duas juntas. (Lévi-Strauss, 2004, p. 151-152)

Por sua capacidade de reunir princípios antagônicos para sua constituição e reprodução (diferentes tipos de descendência, pertencimento por consanguinidade ou por afinidade), os grupos de tipo Casa representariam

(...) um esforço para transcender, em todos os campos da vida coletiva, princípios teoricamente inconciliáveis. Ao colocar, digamos, 'dois em um', a casa realiza uma espécie de giro topológico do interior para o exterior, ela substitui uma dualidade interna por uma unidade externa (ibid., p. 161; grifos meus). 
Em suas primeiras ocorrências na obra de Lévi-Strauss, as "sociedades de casas" aparecem como um "tipo social", um modelo de sociedade que estaria a meio caminho (em termos lógicos, e não evolutivos, como LéviStrauss enfatiza ${ }^{4}$ ) entre as estruturas elementares e as estruturas complexas de parentesco. Diferentemente das primeiras, nas sociedades de casas a política e a economia seriam realidades mais descoladas das relações de consanguinidade e afinidade, mas cuja autonomia ainda incipiente as obrigaria a se expressar na única linguagem disponível, subvertendo-a: a linguagem do parentesco. Mas, justamente por isso, elas não se confundiriam com estruturas complexas, nas quais a política e a economia constituiriam sistemas com linguagens próprias.

O conceito de Casa não costuma ser considerado muito rentável para descrever os povos ameríndios (eles não são sequer mencionados por Lévi-Strauss em seus textos sobre o assunto, e no livro organizado por Janet Carsten e Stephen Hugh-Jones ${ }^{5}$ sobre o tema há apenas três artigos contemplando a América do Sul ${ }^{6}$ ). A maioria apresenta sistemas de aliança de tipo dravidiano operando de forma egocentrada, local e, consequentemente, aberta, o que dificultaria a cristalização de unidades sociais do tipo Casa (Viveiros de Castro, 2002a, p. 96). Como observa Gordon (1996, p. 194), a concepção de Lévi-Strauss - das Casas como unidades sociais típicas de sociedades hierarquizadas e voltadas para sua perpetuação no tempo -, dificultaria a aplicação do modelo em sociedades amplamente descritas como igualitárias e com organizações fluidas do ponto de vista da morfologia social. Mas o próprio Lévi-Strauss chama a atenção para formas efêmeras da Casa, como as existentes em Bali, o que permitiria relativizar esse argumento (Lévi-Strauss, 1986, p. 188-195).

Apesar disso, alguns americanistas vêm utilizando esse conceito em diferentes contextos etnográficos, com rendimentos descritivos e analíticos variados. Provavelmente a primeira tentativa é a inovadora descrição de Lea (1986; 1993; 1995a) da organização social Mebengokre (Kayapó). Segundo

${ }^{4}$ Cf. Lamaison e Lévi-Strauss (1987, p. 3).

${ }^{5}$ Carsten e Hugh-Jones (1995).

${ }^{6}$ Hugh-Jones (1995), Lea (1995b) e Rivière (1995). 
ela, a sociedade mebengokre seria formada por um conjunto de Casas, cada qual "uma unidade exogâmica representada por $n$ habitações nas aldeias existentes atualmente" (Lea, 1995a, p. 322), e cujo pertencimento seria transmitido pela via materna. Cada Casa ocupa um lugar específico no círculo residencial, tem sua distinção assegurada por um "patrimônio de nomes pessoais e de prerrogativas (nekrets)" (ibid.) e é qualificada por epítetos referentes aos principais itens que compõem seu patrimônio (ibid., p. 323). Nas palavras de Lea, "o patrimônio cultural da sociedade mebengokre é segmentado pelas Casas cujo conjunto forma uma totalidade" (Lea, 1993, p. 275). Apesar de serem unidades exogâmicas, as Casas não estariam ligadas entre si por nenhuma regra prescritiva de casamento.

De fato, a posse de riquezas materiais e imateriais é uma das características "clássicas" das Casas ${ }^{7}$, o que torna tentadora a aplicação do conceito ao contexto mebengokre. Mas o fato de o pertencimento a uma Casa mebengokre ser exclusivamente matrilateral e de as Casas serem unidades exogâmicas coloca uma questão importante, já levantada por outros pesquisadores (Coelho de Souza, 2002; Gordon, 2006): o que faz desses grupos Casas, no sentido lévi-straussiano, e não "grupos de descendência unilinear", ou linhagens, no sentido britânico clássico? Como Lévi-Strauss enfatiza, o conceito de Casa se aplica a formas sociais desprovidas de princípios claros de descendência (uni ou bilateral) regendo o pertencimento a grupos; ainda, em vez de se definirem como grupos exogâmicos, as Casas combinariam princípios de endogamia e exogamia, tendo em vista questões políticas ou econômicas. Coelho de Souza (2002, p. 631-633) argumenta que o tratamento das Casas mebengokre por Lea evocaria uma visão das funções dos grupos corporados na esfera políticojural: "seus horizontes continuam sendo, de um lado, as 'corporações' intrinsecamente parciais que são as matricasas e, de outro, a totalidade constituída por sua reunião" (Coelho de Souza, 2002, p. 632).

\footnotetext{
7 "Europeia ou indígena, a Casa possui um domínio que consiste tanto em riquezas imateriais quanto materiais" (Lévi-Strauss, 2004, p. 153-154).

Temáticas, Campinas, 21(42)v.1: 75-113, ago./dez. 2013
} 
A aplicação do conceito à organização social tukano, feita por HughJones (1993; 1995), me parece mais próxima de um importante componente das formulações de Lévi-Strauss: a Casa seria produzida pela combinação de princípios antagônicos e pelo mascaramento de uma dualidade interna sob a forma de uma unidade externa (Lévi-Strauss, 1986, p. 204; 2004, p. 163). Como HughJones observa, o conceito de "descendência" é muito importante para as descrições feitas sobre os grupos tukano, enfatizando a patrilinearidade e a hierarquia em sua composição. Contudo o autor argumenta que a situação é mais complexa, e as relações sociais seriam concebidas segundo dois modelos complementares, dos quais a descendência unilinear seria apenas um. Esta seria pertinente em contextos míticos e rituais, que enfatizam a hierarquia; já as relações da vida cotidiana seriam concebidas segundo um modelo cognático e igualitário. Por esse motivo, Hugh-Jones sugere que o conceito de Casa descreveria com mais acuidade a organização social desses grupos do Noroeste Amazônico, pois as casas tukano combinariam dois princípios "normalmente tomados como mutuamente excludentes" (Hugh-Jones, 1993, p. 98) e mascarariam essa dualidade sob a forma da unidade da maloca. Segundo o autor, "essas duas conceituações correspondem a duas leituras diferentes e generizadas [gendered] da casa como uma estrutura física" (Hugh-Jones, 1993, p. 97). Em diferentes contextos, seria possível encontrar "casas" de escalas variadas, como a maloca, os grupos territoriais, os grupos tukano, e até mesmo o cosmos, reproduzindo-se por meio da combinação de princípios antagônicos como masculino/feminino, consanguinidade/afinidade, hierarquia/igualdade.

Há também uma tentativa de aplicar o conceito ao Alto Xingu. Heckenberger $(2005 ; 2011)$ sugere que as parentelas dos chefes alto-xinguanos poderiam ser vistas como Casas, cuja disposição no círculo da aldeia seria uma expressão de suas diferenças hierárquicas: "As casas principais - a tajïfe (quando presente) e sua contraparte oposicional - são assim as 'cabeças' das maiores facções aldeãs, segmentos sociais, o que corresponde às parentelas [kindreds] dos maiores chefes da aldeia, ou 'Casas' (...)" (Heckenberger, 2005, p. 258). Cada Casa de chefe seria formada por um conjunto de habitações: além da habitação do chefe, as casas de sua parentela ao redor formariam com ele uma facção politicamente coesa. Nos Kuikuro, as Casas dos dois 
chefes principais teriam ocupado os polos norte e sul das duas últimas grandes aldeias há cerca de 30 anos, enquanto as casas de outros chefes menos importantes teriam ocupado as regiões leste e oeste (ibid., p. 273). O autor também afirma que essas "Casas Menores" ("Minor Houses") seriam parte das Casas do sul e do norte: "Casas Menores (chefes de alta hierarquia mas subordinados) estão situadas no lado leste ou oeste da aldeia. Elas também são parte das Casas do norte e do sul, através de parentesco e aliança (i.e., suas parentelas ou 'Casas' estão abrigadas nas de seus irmãos mais velhos)" (ibid., p. 258). A principal aldeia Kuikuro atual seria assim composta de duas Casas de chefes, cada uma sendo "um lugar de habitação maior, geralmente formado por múltiplas casas, e também um grupo de parentesco" (ibid., p. 259), capaz de englobar as Casas dos chefes menos importantes.

Uma das ideias expressas no modelo de Heckenberger é a de que as Casas seriam equivalentes a "facções espacializadas", pois ele as define como as “(...) maiores façõoes aldeãs, segmentos sociais (...)" (Heckenberger, 2005, p. 258; grifos meus), ou "um grupo social com dimensões físicas correspondentes a estruturas de casas singulares ou múltiplas" (Heckenberger, 2011, p. 256). Elas agiriam como grupos politicamente coesos, formando um "bloco de votação" ("voting block") (ibid., p. 266) para os assuntos públicos. O que permitiria identificar tais parentelas bilaterais extensas (kindreds) como "segmentos sociais" seria, em parte, sua fixação no espaço aldeão: “(...) Casas (...) são mais duráveis como pessoas compósitas do que chefes individuais (...). Em parte, as Casas principais estão fixas em um lugar e é sua imobilidade física que cimenta sua continuidade" (ibid., p. 275). Para essa continuidade contribuiriam os processos de sucessão da chefia (e a herança de "nomes bonitos" ou "famosos", isto é, nomes de antigos chefes), a transmissão intergeracional da condição de dono/patrocinador de festas para espíritos (itseke), e de "títulos", como o de "dono do centro", "dono do caminho principal" e "dono da aldeia".

Porém Heckenberger oferece uma descrição consideravelmente mecânica desses processos, que, mesmo sendo eventualmente válida entre os Kuikuro, não me parece aplicável ao caso kalapalo. Apesar dos filhos de um chefe poderem ser preparados como seus "substitutos", isso não significa, 
por exemplo, que o filho do chefe principal será, automaticamente, o próximo chefe principal. Da mesma forma, o filho de um "dono de aldeia" ou "dono da casa dos homens" não necessariamente ocupará o lugar de seu pai - entre os Kalapalo, essas posições têm circulado nos últimos sete anos. Por fim, quanto às festas para espíritos, estas não são "propriedades", e sim relações de parentesco entre uma pessoa (um ex-doente) e um espírito (Barcelos Neto, 2008). A perpetuação da festa de uma geração a outra é possível, mas, nos casos que observei, a geração descendente evita permanecer como patrocinadora de tais rituais - há mais um desejo de se livrar de posições de "dono de festa" de uma geração a outra do que de transformá-las em princípios de continuidade. A exceção talvez seja a transmissão de nomes de chefes, pois possuir tais nomes é um importante índice de ascendência nobre ${ }^{8}$. Contudo, é preciso lembrar que a herança de nomes é bilateral, e não se conforma a nenhum princípio de "linearidade".

Para Heckenberger, a noção de Casa funciona como um conceito de grupo corporado na falta destes. Isso fica claro em algumas passagens, como na afirmação de que, apesar dos xinguanos não terem grupos de descendência linear ou metades nomeadas, "a eles não falta linearidade [ineality], sob a forma de grupos do tipo 'Casa', ancestralidade, genealogia, organização semelhante a castas [castelike organization], e hierarquia social”' (Heckenberger, 2005, p. 265; grifos meus). O autor sugere ainda que grupos "acima da família" seriam formados em três níveis institucionais básicos: “(1) casa ou grupo doméstico; (2) grupos de interesse supradomésticos, geralmente formados pelas parentelas nobres [chiefly kindreds] das Casas menores e maiores; e (3) a aldeia (ou cluster galáctico), a 'Grande Casa' nos sistemas regionais" (Heckenberger, 2005, p. 265). Essa diferença de níveis seria acompanhada de uma replicação autossimilar de um mesmo tipo de pessoa, a Casa (entendida como um grupo coeso liderado por um chefe), evocando o conceito de pessoa fractal (Wagner,

\footnotetext{
${ }^{8}$ Utilizo o termo "nobre" (conforme Barcelos Neto, 2003; 2008) para me referir aos chefes e seus parentes em geral, pois mesmo aqueles que não possuem os títulos de anetü ou itankgo (feminino de anetï) também são considerados pessoas diferenciadas pelos Kalapalo (anetü ungugu, "sangue de chefe", ou anetü unkegugu, "descendente de chefe"). Para uma discussão mais detalhada sobre o assunto, ver Guerreiro Júnior (2011b).
} 
1991). Porém seu argumento é ilustrado com uma estrutura hierárquica de tipo segmentar, segundo a qual a condição de chefia [chiefliness]:

(...) através de sistemas hierarquizados de consanguinidade e afinidade, posiciona todos os membros da sociedade xinguana em uma estrutura hierárquica global, que transforma a família e membros do grupo doméstico em líderes de casa, líderes de casa em chefes (os chefes primários da aldeia ou aneti, líderes das parentelas nobres ou Casas), e notavelmente a comunidade em um ou poucos "grandes chefes" hierarquizados (aneti ekugu, ou em certos contextos, mulheres chefes de alta hierarquia, tango). (Heckenberger, 2005, p. 262)

De fato, a imagem por trás desse modelo é a do "clã cônico" polinésio, segundo a qual a distinção entre irmãos mais velhos e mais novos produziria linhas de descendência hierarquizadas entre si, com uma delas ocupando o topo da pirâmide (Sahlins, 1968; Heckenberger, 2005, p. 270). Esse tipo de organização hierárquica é justamente o que não existe na política xinguana, pois todas as etnografias atestam a variabilidade com que a condição de "chefe principal", ou "primeiro cacique", se transmite. A primazia da chefia, apesar de idealmente transmitir-se de um pai para seu filho mais velho (o que permitiria reproduzir "linhas de descendência" e a organização "castelike" descrita por Heckenberger), frequentemente circula entre chefes rivais, dificilmente se estabilizando em "linhas de descendência". Ela não é um "posto", como nos chiefdoms polinésios em que se baseia Heckenberger, mas uma condição pessoal que, como tal, encontra-se sujeita a inúmeras contingências. Na aldeia Aiha, onde desenvolvo pesquisa de campo, o chefe principal indicou como seu substituto seu sobrinho uterino, apesar de ter dois filhos homens já considerados anetü (é relativamente comum que filhos de chefes não assumam a posição do

\footnotetext{
${ }^{9}$ Os Kalapalo hierarquizam seus principais chefes em "primeiro, segundo e terceiro caciques". Como são expressões muito comuns, utilizo-as como se fossem "categorias nativas", e por isso aparecem italicizadas.
} 
pai). Esse rapaz, por sua vez, descende ao mesmo tempo dos dois maiores chefes rivais de Aiha, como se vê pelos trabalhos de Basso (1973). Ele é herdeiro de "nomes famosos" tanto pelo lado materno quanto paterno, e tem sua casa posicionada distante da casa do chefe principal (cujos parentes próximos, até mesmo alguns de seus apoiadores, encontram-se espalhados pela aldeia). Ou seja, não há nada na sucessão atualmente em curso entre os Kalapalo que permita identificar "Casas" como os grupos "lineares", politicamente coesos e fixados no espaço, descritos por Heckenberger entre os Kuikuro.

Além disso, é exatamente contra esse tipo de estrutura hierárquicosegmentar que se volta o conceito de pessoa fractal, tal como evocado por Wagner (1991) e Strathern (1991). Um fractal não é formado por unidades cada vez mais englobantes; por definição, ao sair de um ponto ínfimo de um fractal e passar para uma visão mais ampla da mesma figura, não vemos outra coisa senão a mesma figura. Isso talvez seja a forma visual mais clara da ideia, associada aos fractais, de que "as relações externas são internas": quando se olha para fora, vê-se o que já se via dentro, e vice-versa. Como pretendo mostrar a seguir, se há algo que se replica de forma autossimilar em diferentes escalas, oferecendo uma imagem fractal para diferentes facetas da socialidade alto-xinguana, é o "corpo nobre", capaz de se objetificar sob formas diversas ${ }^{10}$.

Em seus últimos desenvolvimentos da noção de Casa, Lévi-Strauss intentava oferecer uma alternativa não só à ideia de grupo de descendência unilinear, mas à própria noção de grupo corporado (Lévi-Strauss, 1986, p. 188-191), e é aí que sugiro procurar seu rendimento. Coelho de Souza argumenta nesse mesmo sentido, observando que o conceito de Casa, "além de pretender completar uma tipologia - a do próprio Lévi-Strauss, para a qual os sistemas pós-elementares de descendência cognática punham problemas consideráveis - se desenvolve também como resposta crítica às teorias britânicas da corporação" (Coelho de Souza, 2002, p. 631). Entre os Kalapalo, é possível encontrar referências a certas "casas" que convidam a um diálogo com algumas

${ }^{10}$ Em um artigo recente, Heckenberger aponta em sentido semelhante, mas acaba retomando o modelo hierárquico-segmentar (Heckenberger, 2011, p. 256). 
formulações do conceito. Minha intenção é mostrar que a chefia xinguana pode ser pensada como uma Casa, não por questões de espacialidade, transmissão de riquezas ou hierarquia (o que, como já argumentei em outro trabalho, é mais uma versão dos modelos apoiados em ideias ocidentais de economia política; cf. Guerreiro Júnior, 2011b), mas por objetivar sob a forma de unidade uma relação tensa inerente à afinidade. Assim como as Casas na Indonésia e na Melanésia, a chefia xinguana não se funda na descendência, na residência ou na transmissão de propriedade, mas na relação de afinidade, fonte ao mesmo tempo de unidade e antagonismo (Lévi-Strauss, 1986, p. 188-204). No Alto Xingu, porém, esse princípio de "unidade e antagonismo" não é a afinidade efetiva, mas a afinidade potencial -- a afinidade em sua forma pura, desvinculada da aliança matrimonial de fato e marcada pela inimizade (cf. Viveiros de Castro, 2002a).

A seguir, descrevo dois tipos de "casas" - o túmulo-casa de um nobre após a morte (o tahiti) e a residência ideal de um grande chefe em vida (a talühe) -, procurando mostrar como essas estruturas guardam analogias com o modelo de corpo dos chefes, uma forma marcada pelas dualidades humano/não humano, consanguíneo/afim, protetor/predador.

\section{CASAS PARA CHEFES MORTOS: O TAHITI}

Quando morre um chefe ou algum de seus parentes próximos, outros chefes podem sugerir que se realize um ritual mortuário em homenagem ao falecido, chamado egitsï em kalapalo e amplamente conhecido como Quarup ${ }^{11}$. Trata-se de um longo ciclo, de mais ou menos um ano, que culmina com a produção, exibição e descarte de pelo menos uma efígie de madeira, que presentifica o morto durante o último dia e a última noite do ritual, que se encerra com embates da luta xinguana (ikindene) entre o povo anfitrião e seus vizinhos convidados (Guerreiro Júnior, 2011c).

Um dos momentos mais importantes do ciclo do Quarup é a construção de uma espécie de cerca ao redor da sepultura do morto, chamada

${ }^{11}$ Corruptela em português da palavra kamayurá kwaryp. 
tabiti. Essa estrutura é construída com pequenos pedaços de uma madeira chamada $u^{1 / 2 g u ̈ b i i^{12}}$, a mesma com a qual o demiurgo Kuatüngü produziu as mulheres de madeira que enviou para se casarem com Enitsu¹/2gü, a onça chefe dos animais terrestres, uma das quais deu à luz os gêmeos Taigi e Aulukumã, criadores da humanidade. Essa também é a madeira com a qual os gêmeos realizaram o primeiro Quarup, em homenagem à sua mãe, e com a qual atualmente são feitas as efígies mortuárias. Trata-se de uma árvore que pode atingir cerca de 20 metros de altura, possui um tronco de circunferência muito regular e é bastante dura, pesada e resistente. Por essas características, ela é considerada uma árvore especialmente bela, e é tida como o "chefe das árvores" (cujo espírito, além de ser um grande chefe, também é um grande mestre de luta).

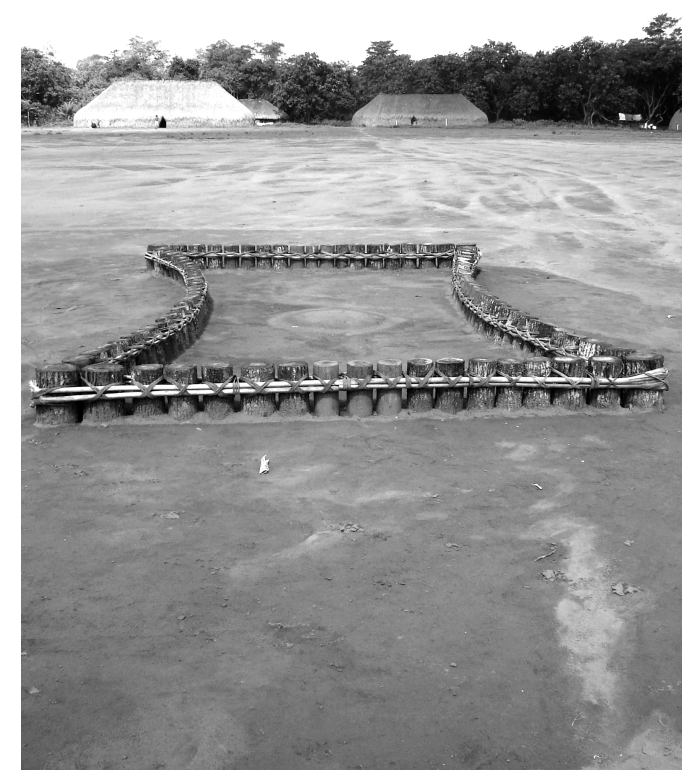

${ }^{12}$ Essa árvore não possui nenhum nome popular em português no Alto Xingu, mas foi identificada como sendo da espécie Humiria balsamifera var. floribunda (Emmerich, Emmerich e Valle, 1987), conhecida no norte do Brasil como Umiri.

Temáticas, Campinas, 21(42)v.1: 75-113, ago./dez. 2013 
Os Kalapalo dizem que o tabitié a "casa do morto". Não se trata de uma casa qualquer, mas uma talïhe, uma "casa de chefe" (que será discutida adiante), construída ao mesmo tempo para o morto pelos vivos, e para uma de suas almas - o "dono do olho" - pelos mortos. O dono do olho é uma das almas que, com a morte, se desprende do corpo, retém forma humana eternamente e habita a aldeia dos mortos, no céu. Na ocasião da construção do tahiti pelos vivos, os mortos constroem uma talïhe em sua aldeia celeste ${ }^{13}$, onde o morto irá morar quando sair de sua reclusão (pois os mortos chegam fracos ao céu, e passam um período reclusos na casa de seu pai para se fortalecerem e ficarem belos; dali só saem por ocasião de um eclipse ou de sua homenagem no ritual mortuário). Entre os vivos, espera-se que o tabiti atraia a alma-sombra do morto, outro aspecto da pessoa que, ao se desprender do corpo, passa a viver junto a algum espírito-animal (itseke), a assemelhar seu corpo ao desses seres e a assumir seu ponto de vista (isto é, torna-se seu parente). Retomarei este ponto adiante. No momento, meu foco incide sobre a forma do tahitie as relações que ela ao mesmo tempo evidencia e oculta.

$\mathrm{O}$ tabiti tem uma forma presente em várias pinturas alto-xinguanas, de dois arcos em elipse com as aberturas voltadas para fora ${ }^{14}$. Há indícios de que essa seja a forma básica de um corpo humano, os traços mínimos com os quais se pode representar uma pessoa. Segundo Coelho (1993, p. 611), os Wauja sempre desenham o tronco de uma figura antropomorfa com esse motivo (e pode-se dizer o mesmo sobre os Kalapalo). Eles o chamam de atirruá, que seria uma "pintura de borboleta" ou a pintura de um peixe parecido com o acari, uma espécie de "cascudo" (da família Loricariidae) que teria sido mensageiro no Quarup mítico (possivelmente o mesmo que aparece na mitologia kalapalo, chamado kagi-kagi). Coelho também nota que esse motivo

\footnotetext{
${ }^{13}$ Os chefes mortos parecem valorizar esse esforço. Um rapaz, filho de chefe, sonhou com a alma de seu pai morto contando-lhe, maravilhado, sobre a imensa talïhe que seus parentes haviam construído para ele no céu, descrevendo em detalhes sua altura, a largura dos pilares da porta e sua decoração.

${ }^{14}$ Segundo Pedro Agostinho, os Kamayurá fariam esse desenho no teto da casa do chefe principal da aldeia, "e só nela, distinguindo-a das demais" (Agostinho, 1974, p. 28). Pude observar o mesmo na casa do chefe Yawalapíti.
} 
é pintado com urucum nas costas dos mensageiros enviados para convidar outra aldeia a um Quarup, quando os chefes desta última os sentam no centro da aldeia e aceitam formalmente seu convite. Entre os Kalapalo, também se aplica o mesmo motivo nas costas dos mensageiros nesse contexto, mas, a despeito de sua forma idêntica, dizem se tratar de "outro desenho", chamado de urubu (kuguagl $)$. Isso talvez possa ser explicado pela associação dos urubus aos bancos rituais dos chefes ${ }^{15}$, pois a imagem "clássica" do Urubu-Rei Bicéfalo (ugubu ku1/2gï), um dos chefes das aves, é sentado em seu banco enquanto ressuscita pássaros derrotados em batalhas celestes contra os mortos. Pintar os mensageiros "como urubus" seria um sinal para os chefes que os enviaram de que eles "se sentaram", e que o convite foi aceito. Isso estaria em consonância com o nome kamayurá dessa pintura segundo Agostinho (1974, p. 29), apikap, que significa "banco"16.

Barcelos Neto (2008, p. 212-213) também afirma que esse motivo gráfico é um esquema alusivo à antropomorfia, no qual "os arcos configuram o tronco dos seres antropomorfos" (ibid., p. 213). O autor nota que os arcos em elipse estão presentes em diversos artefatos wauja, como as grandes máscaras atujua (atugua, em kalapalo), as pás de virar beiju, as grandes panelas de cerâmica e todas as máscaras de tipo Sapukuyawá. Não conheço uma máscara equivalente entre os kalapalo, mas também é possível encontrar esse motivo em outras máscaras, como na kuambü, usada por seres aquáticos (Figura 2):

\footnotetext{
${ }^{15}$ Nos rituais regionais, os chefes dos povos convidados permanecem sentados em bancos de madeira (ugi). Esses bancos podem ser zoomorfos, e aqueles com formato de urubu bicéfalo são considerados de uso exclusivo dos chefes.

${ }^{16}$ Agostinho (1974, p. 28-29) diz que esse motivo gráfico também seria chamado de "“caminho da mangaba', ou campo do jogo de bola", em referência ao formato do campo no qual se praticava um jogo com uma bola feita da seiva da mangabeira (chamado katuga ikugu em kalapalo; lit. "seiva de mangaba").
} 


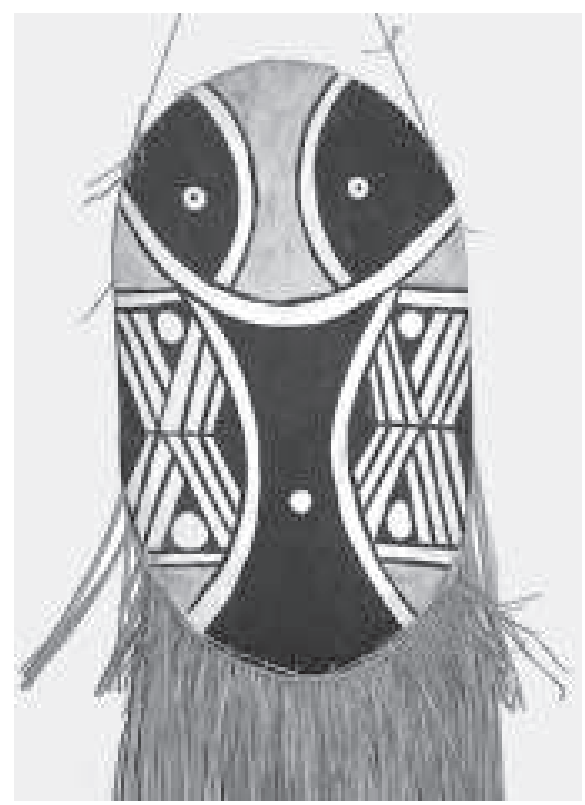

Figura 2: kuambü, uma das máscaras usadas por seres aquáticos quando aparecem para os humanos.

A maior área na qual se aplica o motivo (pintada de preto) é descrita como o corpo/tronco (ibii) da máscara/espírito, e na área externa, à esquerda e à direita (suas "laterais do tronco", ijatiu), aplicam-se padrões típicos da pintura corporal xinguana (no caso, um motivo de "escamas de peixe"). $\mathrm{Na}$ parte superior, o motivo reaparece, delineando seu "rosto", uma relação também presente nas máscaras atugua (o motivo também é chamado de "rosto de atujua" pelos Wauja, quando aplicado no fundo de panelas; Barcelos Neto, 2008, p. 216). Ainda segundo Barcelos Neto, a questão é saber por que um mesmo esquema seria aplicado a objetos aparentemente tão diferentes, ligando todos a uma ideia elementar de antropomorfia. Isso estaria associado à condição ambígua de objetos e espíritos, que podem ser, ao mesmo tempo, coisas e pessoas. $\mathrm{O}$ "aspecto pessoa" de qualquer ser está necessariamente ligado ao corpo, pois alguém só aparece como pessoa na medida em que 
apresenta um corpo antropomorfo. Os arcos em elipse traduziriam a ideia de antropomorfia em uma forma visual, efetuando uma "síntese formal" (Barcelos Neto, 2008, p. 217) entre um conjunto de artefatos:

(...) é por meio de uma esquematização, expressa por determinados motivos gráficos ou formas plásticas, que yerupoho/apapaatai [“espíritos", em wauja], objetos e pessoas adquirem uma continuidade que é pensada como antropomorfia. Ou seja, o conceito de antropomorfia seria dependente da sua possibilidade de ser visualmente sintetizado. (Barcelos Neto, 2008, p. 215).

Também é possível especular que essa forma geométrica seja a mesma a partir da qual é feita a "moldura" básica da pintura corporal masculina, tal como delineada no tronco humano (Figura 3):

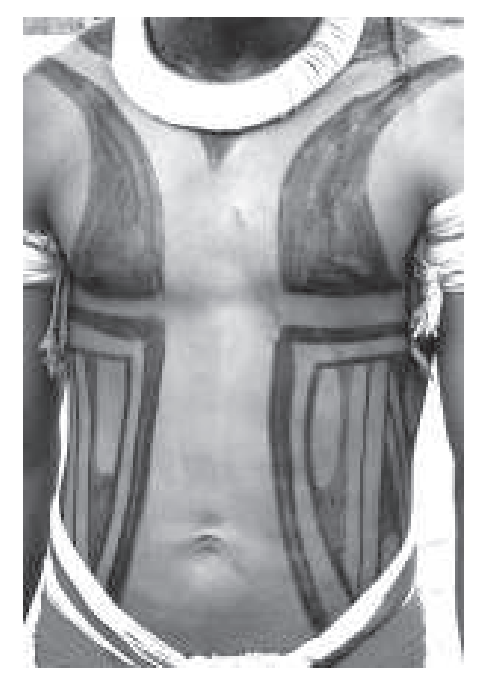

Figura 3: pintura corporal masculina, cujos contornos básicos evocam o motivo das elipses. 
Não são só espíritos e objetos que precisam ter sua faceta humana tornada visível por índices formais-corporais, mas também os humanos em situações rituais, quando geralmente têm seus corpos intencionalmente transformados. Afinal, se um corpo não se apresenta como humano, que tipo de pessoa poderia ser? Ou melhor, como é possível ativar capacidades corporais de outros seres (como onças, peixes e aves que povoam tantos rituais xinguanos) e manter-se humano ao mesmo tempo? Indicativo da condição de Pessoa, o uso de tal motivo para a construção dos túmulos-casa dos chefes está em parte ligado à condição desses agentes perante os não chefes: somente os primeiros são considerados propriamente "gente" (kuge), resultado de um processo de fabricação do corpo muito mais longo e cuidadoso que o normal ${ }^{17}$. Quando, por exemplo, se questiona se alguém é kuge (gente), é uma forma indireta de perguntar se a pessoa é anetü (chefe).

Segundo Von den Steinen (1940), os Mehinaku tatuavam esse motivo em alguns homens (acompanhando o bordo interno da omoplata) e mulheres (nos braços). Agostinho diz ter ouvido dos Kamayurá que

(...) em tempos antigos os chefes tatuavam esse desenho sobre o peito, verticalmente: os dois arcos aproximavam-se a meio do esterno, deixando os mamilos de fora, e iam das clavículas quase à cintura, sem que linhas os unissem em cima e embaixo, limitando o espaço circunscrito. A tatuagem era conhecida como irivutsi(n)ng ara(n)ngap, "figura de urubu-rei” (...). (Agostinho, 1974, p. 29; grifos no original)

Nenhum kalapalo pôde confirmar essa informação, e meus interlocutores dizem nunca terem ouvido falar dessas tatuagens (mas a semelhança entre sua descrição e a moldura da pintura corporal masculina, como aparece na Figura 3, é digna de nota, bem como sua associação ao urubu-rei). Sabe-se, contudo, que entre os Mehinaku (assim como entre os

\footnotetext{
${ }^{17}$ Enquanto a maioria dos meninos fica reclusa por um ou dois anos, aqueles preparados para se tornarem grandes chefes podem ficar nessa condição por até uma década. 
Kamayurá e Aweti) é comum tatuar mulheres nobres usando um motivo de três linhas horizontais paralelas dispostas no braço, um pouco abaixo do ombro, ou no pulso. Se a tatuagem contemporânea está associada à chefia, é possível especular que as tatuagens observadas por Von den Steinen e as evocadas por Agostinho também estivessem. Se assim fosse, novamente esse motivo gráfico apareceria ligado à condição de pessoa, pois, como observei, comparados às pessoas comuns, somente os chefes são efetivamente kuge - gente.

Tendo em mente a associação entre esse motivo e a antropomorfia, vemos que o tahiti é de fato concebido como uma espécie de corpo (Figura 4), que possui orelhas (ihangagiu), testa (ibinitiu) e "laterais do tronco" (ijatiu). As orelhas são feitas com pedaços um pouco mais grossos de $u^{1 / 2 g}$ gïhi, enquanto as outras duas partes são feitas da tabaku, uma madeira mais clara (não identificada por mim), com o objetivo de provocar contraste:

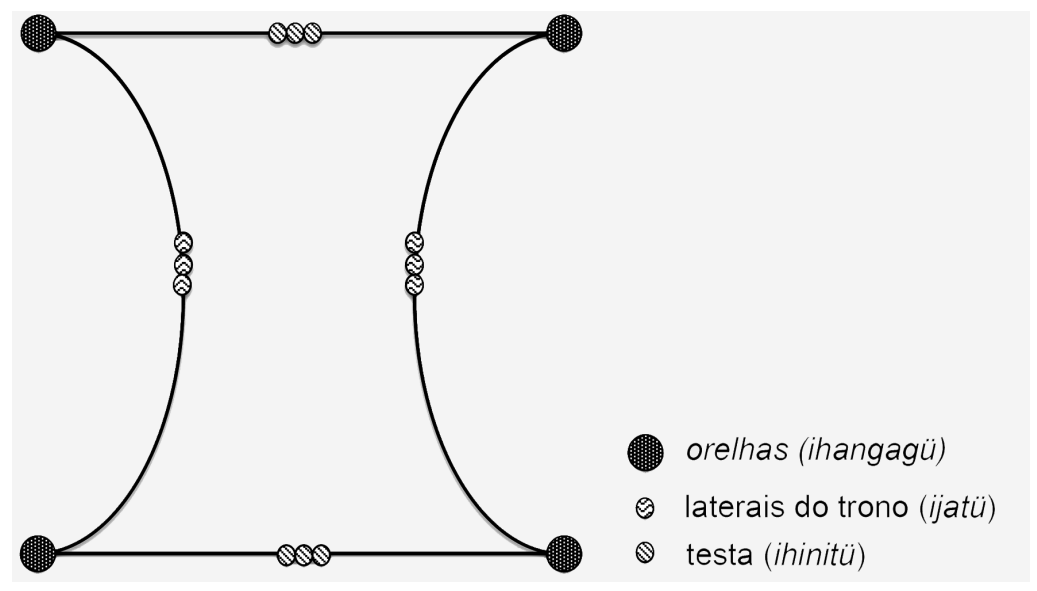

Figura 4: "anatomia" do tabiti. Note-se a existência de duas testas e dois pares de orelhas, evocando um corpo bicéfalo (condição do Urubu-Rei, insígnia de chefia). 
Há uma importante aproximação entre a construção do tabiti para um chefe morto e a fabricação de máscaras para espíritos, pois o tahiti tem como um de seus propósitos manter os laços da alma-sombra do morto (que, ao se desprender do corpo, vai viver junto a algum espírito não humano) com a aldeia. Essa complexa estrutura, que é ao mesmo tempo sepultura, casa e corpo, torna manifesto que ali está uma Pessoa/sujeito, um(a) kuge, um chefe. Mas ele não apenas "representa" o chefe morto, pois sabe-se que uma das marcas da arte xinguana é a capacidade de tornar atual, presente, aquilo cuja forma se constrói (Barcelos Neto, 2008). Fazer uma máscara é trazer um espírito para o convívio dos humanos, desenhar uma anta é atrair esse animal para as roças. Segundo a mesma lógica, fazer um corpo-casa para um morto é como refazer seu corpo e colocá-lo para habitar o centro da aldeia. O morto ganha uma casa, mas não no círculo da aldeia, e sim no centro, lugar próprio aos espíritos - onde a alteridade pode aparecer de forma controlada e produtiva.

A alimentação desempenha um papel importante nisso, assim como nos rituais para espíritos (e, de fato, em qualquer processo de aparentamento). Enquanto o tahiti for mantido, os parentes próximos do morto deverão depositar, periodicamente, uma pequena panela com mingau de pequi em seu interior. Esse mingau serve para matar a sede do morto, porém, mais do que para isso, serve para atrair sua alma-sombra para sua nova casa junto aos humanos. Alimentar um espírito é uma forma de humanizá-lo, e atraí-lo para o ponto de vista dos humanos significa aparentá-lo. A construção do tabitié uma forma de domesticar a alma-sombra do chefe (parcialmente metamorfoseada em espírito-animal) e mantê-la humana (ao menos por um tempo), e, se um ritual de máscaras marca uma relação entre um itseke e uma pessoa, a construção do tahiti marca uma relação coletiva entre um chefe e seu povo.

Esse esforço só é despendido para os nobres, pois intenta-se transformá-los em "ancestrais" () bigu) e viabilizar a continuidade da produção de chefes no presente. Foi o que os gêmeos fizeram com sua mãe, ao construírem para ela o primeiro tabiti: fizeram dela o primeiro ancestral dos humanos, de quem eles próprios foram os primeiros substitutos. Os chefes 
humanos não são considerados seus "descendentes" diretos, mas há um mito kalapalo segundo o qual os primeiros chefes teriam sido feitos como tais por Taigi, que patrocinou para eles um ritual de furação de orelhas como se estes fossem seus próprios filhos (produzindo uma relação que poderia ser chamada de "ancestralidade ritual"). Se, como alhures na Amazônia indígena, o parentesco e a condição humana são coextensivos (Gow, 1997; Coelho de Souza, 2004), para transformar um chefe morto em ancestral é preciso mantê-lo como parente, e, para isso, é preciso mantê-lo humano. Como entre outros povos ameríndios, a ancestralidade aqui é embebida em diferença (Erikson, 2007), e é justamente isso que a estética do tahiti, seu local de construção e seus propósitos tornam evidente.

Mas por que presentificar o morto por meio de um processo que lembra a confecção de máscaras? Assim como um itseke familiarizado, o morto também é meio espírito, meio humano. Sua alma-sombra já vive junto a um espírito-animal e, como tal, seu corpo já não é completamente antropomorfo (do ponto de vista dos vivos). Porém há mais, pois o próprio chefe é um tipo de pessoa produzida para exibir índices da mais perfeita humanidade e da mais perigosa alteridade: para ser chefe, por um lado é preciso ser um modelo do humano, o que resulta da fabricação de um corpo ideal (cujo arquétipo mítico, o corpo da mãe dos gêmeos, foi produzido a partir de um tronco de $\left.u^{1} / 2 g \ddot{z} h \imath\right)$; por outro, é preciso ser diferente, o que aqui está dado na alteridade da alma-sombra, mas em outros contextos é tornado visível pelo uso de insígnias de grandes predadores, como a onça, o gavião e a sucuri (como ficará claro a partir da próxima seção). É como se a forma do tahiti humanizasse aquilo sobre o que se aplica - objetos, máscaras de espíritos e até mesmo corpos humanos teriam, com ela, sua condição de gente/pessoa tornada manifesta -, mas sem deixar de marcar sua alteridade. Esse túmulocasa-corpo que é o tahiti, ao mesmo tempo que antropomorfiza e humaniza, opera como índice da alteridade do sujeito objetificado. 


\section{CASAS PARA CHEFES VIVOS: A TALÜHE}

As habitações xinguanas são pensadas como corpos masculinos: possuem tronco, costelas, axilas, pescoço, cabeça, colar, plumária, e estão armadas com uma lança de pesca. Vistas de fora, as casas são análogas ao corpo de um pescador paramentado para a festa, reunindo os dois elementos que os xinguanos consideram seus diferenciais: a prática de seus rituais e a centralidade dos peixes em seu sistema alimentar. De fato, em certas situações as casas podem ser mesmo equiparadas a pessoas. Levei um grande susto em 2009 quando dois rapazes que estavam em Brasília me disseram que, depois da saída de algumas pessoas da aldeia, o local estaria com apenas " 17 pessoas". Lembrando do que diz Lima (2005) sobre como os Yudjá contam as pessoas ${ }^{18}$, imaginei que esse número pudesse se referir aos homens adultos da aldeia, mas ainda assim me parecia muito pouco. Quando cheguei à aldeia, vi que ela estava cheia, não parecia ter se esvaziado tanto, e havia muito mais do que 17 homens adultos. Havia, porém, apenas 17 casas.

As casas alto-xinguanas típicas são grandes estruturas ovaladas feitas com diferentes tipos de madeira, bambu, embira e sapé. Segundo medições de Heckenberger (2005, p. 257) na aldeia kuikuro Ipatse, o comprimento das casas varia entre 11 e 35 metros, sua altura entre 3,5 e 7 metros, e sua largura entre 6 e 14 metros. A maior casa medida por ele teria sido a talühe da aldeia kalapalo, com 50 metros de comprimento. Toda casa tem um dono, necessariamente um homem, que foi o responsável por decidir sua construção e organizar o trabalho para tanto. Isso só muda quando um genro organiza a construção da casa de seu sogro, caso more com ele, o que é mais ou menos frequente quando o sogro já está muito velho ou não conta com parentes suficientes para ajudá-lo. Nessas situações, é obrigação do genro construir sua casa, e a condição de dono se torna ambígua: algumas pessoas dirão que

\footnotetext{
${ }^{18}$ Segundo a autora, quando os Yudjá dizem “uma pessoa”, eles se referem a alguém que assume a posição de sujeito em um grupo e aqueles que são "eclipsados" por sua posição (Lima, 2005, p. 76). Por exemplo, "uma pessoa" pode significar um-homem-e-sua-família, situação na qual apenas o homem é tomado como sujeito.
} 
o dono é o genro, porque organizou o trabalho, enquanto outras dirão que o dono é o sogro.

Toda casa que segue os padrões ideais de construção (as "casas de verdade", distintas das casas provisórias) é construída em duas metades: a da esquerda deve ser feita pelo dono e seus parentes masculinos, e a da direita é construída com a ajuda dos outros homens da aldeia, que recebem alimento como pagamento. A relação entre o dono da casa em construção e os demais trabalhadores carrega traços de afinidade, pois o trabalho coletivo em uma casa é uma oportunidade para primos cruzados (afins terminológicos) entrarem em relações ao mesmo tempo tensas e cooperativas. Nessas ocasiões, qualquer primo cruzado do dono da casa em construção pode pedir um pagamento adicional por seu trabalho. Quando alguém o faz, aproveita para pedir pagamentos caros ou coisas complicadas para o dono ${ }^{19}$, como uma espécie de desafio a seu primo cruzado (que não pode recusar). Em contrapartida, espera-se que esses primos trabalhem duro e ajudem na coordenação do trabalho (dizem que eles ficam "igual a tajope", isto é, "coordenadores" das atividades coletivas). Como se fosse uma pessoa, uma casa é o produto da relação entre consanguíneos e afins, ainda que nesse caso se trate dos afins terminológicos.

Um dos principais índices de que alguém é um grande chefe é ele viver, ou já ter vivido, em uma talïhe. Essa casa tem um papel importante para a planta da aldeia, pois ela divide o círculo de casas - do ponto de vista de quem olha a talïhe de frente a partir da praça - em esquerda (ibe)gü inhongo) e direita (oto inhong ${ }^{20}$ ). Seu local ideal de construção é a leste, de frente para a casa dos homens e para a entrada principal da aldeia (o que, contudo, não é

\footnotetext{
${ }^{19} \mathrm{Um}$ homem foi pescar com seus três filhos e seu genro para pagar a comunidade pelo trabalho em sua casa. Eles passaram a noite pescando, pois o trabalho começaria de manhã. Logo cedo, enquanto cobriam a casa com sapé, um primo cruzado do dono da casa gritou e pediu... peixe! O dono ficou visivelmente irritado, mas, sem manifestá-lo, aceitou - não havia alternativa. Naquele mesmo dia ele teve que ir pescar novamente e trazer peixe exclusivamente para a casa de seu primo cruzado. Tempos depois, comentando o ocorrido comigo, desabafou: "nossos primos cruzados são loucos!".

${ }^{20}$ Lit. "em direção ao dono".
} 
uma regra); quando construída nesse polo, a oposição entre esquerda e direita se sobrepõe àquela entre norte e sul. Uma casa como essa nem sempre existe em uma aldeia, mas há um ideal de que, tendo a aldeia um grande chefe (seu primeiro cacique), este deveria morar em uma talïhe. Aiha contava com 25 casas em agosto de 2011; contudo lá não há nenhuma talühe atualmente, e a última foi destruída em 2007, quando já estava muito velha ${ }^{21}$.

A talïhe aparece pela primeira vez no mito de origem da humanidade como a casa da onça mítica Enitsu1/2gü (pai dos gêmeos Taigi e Aulukumã). Quando os gêmeos se mudaram para sua aldeia em Mügena (região de confluência dos formadores do Xingu), Taigi construiu para si uma casa como a de seu pai-onça, que teria dado origem à construção de casas especiais para chefes humanos. Assim, se o túmulo-casa nobre (tabiti), por seu material de construção (a madeira $u^{1 / 2 g u ̈ h} \imath$ ) e sua origem mítica, evoca a mãe humanaarbórea dos gêmeos, a talïhe evoca seu pai onça-animal. Diferentemente de uma casa comum, um chefe jamais pode decidir pela construção de sua própria talïhe. Isso deve ser uma sugestão de outros chefes que, se for aceita pelos demais, ainda pode ou não ser aceita por aquele que viverá na casa ${ }^{22}$. Quatro chefes (como em outras atividades direcionadas aos nobres ${ }^{23}$ ) se tornam

\footnotetext{
${ }^{21}$ Por isso infelizmente não disponho de imagens que sejam representativas desse tipo de construção, já que em 2007 toda a decoração estava deteriorada.

${ }^{22}$ Segundo o chefe principal de Aiha, ele nunca passou por nada tão desgastante como quando construíram sua talïhe. Pescava todos os dias, com a ajuda apenas de seus dois filhos homens e seu único genro à época, e só contava com uma filha adulta. Sua mulher me contou ter sugerido a ele que arranjasse uma segunda esposa, pois ela não aguentava mais trabalhar. Nas palavras do chefe, hoje: "eu não quero mais saber de talübe!".

${ }^{23}$ É importante notar a recorrência do número de "coordenadores" (tajope) que organizam as atividades rituais para a nobreza: são precisos quatro para enterrar um chefe, quatro para construir um tahiti, quatro para coordenar um Quarup, e quatro para construir uma talübe. Haveria alguma relação entre este número e a forma mínima de uma aldeia circular? O mínimo para que uma aldeia xinguana tenha um centro e uma casa dos homens são quatro casas. Se o chefe é, ao menos em alguns momentos, uma espécie de "centro" da vida social (como a própria praça da aldeia), pode-se pensar que o mínimo para a produção desse(s) centro(s) também são quatro pessoas. Outra coisa interessante é a distribuição dos tajope, no enterro, na construção do tabiti e na construção de uma talühe, em dois grupos de dois: nos dois primeiros casos, são dois enterradores para o leste e dois para o oeste; no caso da talühe, são dois responsáveis pela metade da esquerda (idealmente norte), e dois pela metade da direita (idealmente sul).
} 
responsáveis por coordenar a construção da talühe e transformam seu futuro morador em dono de alguma festa, que será realizada praticamente todos os dias até o final da construção. Ao prover peixe, beiju e mingau para a festa, o chefe paga pela construção de sua casa.

Essa casa é um investimento do coletivo em uma pessoa que se espera que permaneça chefe, ou então que se torne um grande anetü. Em Aiha, o atual chefe principal só teve sua talïhe construída em uma situação política tensa: quando outro chefe se mudou para a aldeia, a pedido dos próprios Kalapalo, para se tornar o "dono dos brancos" (responsável por intermediar o contato com agentes não indígenas ${ }^{24}$. Construindo uma casa para ele, os Kalapalo afirmaram sua posição como primeiro cacique em uma conjuntura política potencialmente tensa. Atualmente, esse homem está sendo substituído por seu sobrinho uterino, para quem a aldeia planeja construir uma talïhe em breve. Ou seja, ao construírem uma talühe, os Kalapalo também estão construindo um chefe - outro "corpo nobre", em outra escala. A analogia com a fabricação do corpo não é fortuita. As principais marcas de nobreza exibidas pelos chefes em seu corpo, em diferentes contextos ao longo de toda uma vida de participação em rituais, são sintetizadas na talïhe, e tornam visíveis uma dualidade entre superconsanguinidade/humanidade e afinidade potencial/não humanidade, já evocada acerca do tabiti.

Uma talïhe pode ser identificada pela exibição de raízes de árvores nas extremidades externas do teto ${ }^{25}$, chamadas de "orelhas" ou "brincos", um índice de que a casa foi construída coletivamente (além da talïhe, apenas a "casa dos homens" possui esse tipo de adereço). Dizem que isso serve para que qualquer pessoa vinda de fora logo saiba onde vive o chefe principal. Ainda, ela tem orelhas porque "o chefe precisa escutar as pessoas", e sua casa é um lugar onde se deve falar de coisas sérias. Certa vez um rapaz me disse que a casa do futuro chefe, apesar de (ainda) ser uma casa comum, “já é uma

\footnotetext{
${ }^{24}$ Uma discussão detalhada sobre o papel de "dono dos brancos" pode ser encontrada em Guerreiro Júnior (2010).

${ }^{25}$ Isso é feito amarrando nas extremidades do teto parte de alguma árvore de tronco bem fino com suas raízes.
} 
talïhe, você vê que as pessoas vão lá o dia inteiro pra conversar". Essa afirmação é sugestiva da mútua produção entre chefes e casas, pois, assim como uma Casa atua na produção de um chefe, este também contribui para atribuir a condição de talühe ao local onde vive.

Esses brincos da talïhe seriam como os brincos feitos com penas de rabo de rei-congo (küngüa; Psarocolius decumanus), de uso exclusivo dos chefes em contextos rituais (usados sempre pelos donos do Quarup, feitos pelos coordenadores do ritual). Versões invisíveis desses brincos são usadas por espíritos e grandes xamãs, e lhes conferem a capacidade de escutar a longas distâncias. Isso evoca a discussão de Seeger (1975) sobre adornos corporais, segundo a qual a ornamentação do corpo estaria ligada à importância simbólica de certas faculdades. Seeger argumenta que, para os homens Suyá (K)œsêdjê), suas orelhas seriam ornamentadas com alargadores e seus lábios com botoques porque esses são os órgãos ligados às principais faculdades de um homem, a audição e a fala. Esses ornamentos seriam "representações físicas da elaboração conceitual" (Seeger, 1975, p. 218) de tais capacidades. Vista de fora, a talühe é como um homem xinguano portando brincos, que, em contextos rituais, são insígnias da posição de chefe e estão ligados a uma capacidade auditiva exacerbada.

A talïhe também apresenta, sobre o teto, um friso externo com pinturas, no qual se aplica (pelo menos) um desenho que representa a junção das asas de uma borboleta a seu corpo (bototo ijatagü; lit. "axila de borboleta"). Esse desenho pode ser combinado a outros, como o principal padrão da pintura corporal (tüibitinhiu) e o motivo das efígies mortuárias masculinas (outro tipo de "axila de borboleta"). Dois frisos idênticos são colocados no interior da casa sobre as portas frontal e traseira, ao longo de todo o seu comprimento. Abaixo, um friso desse tipo no teto da casa dos homens (Figura 5): 


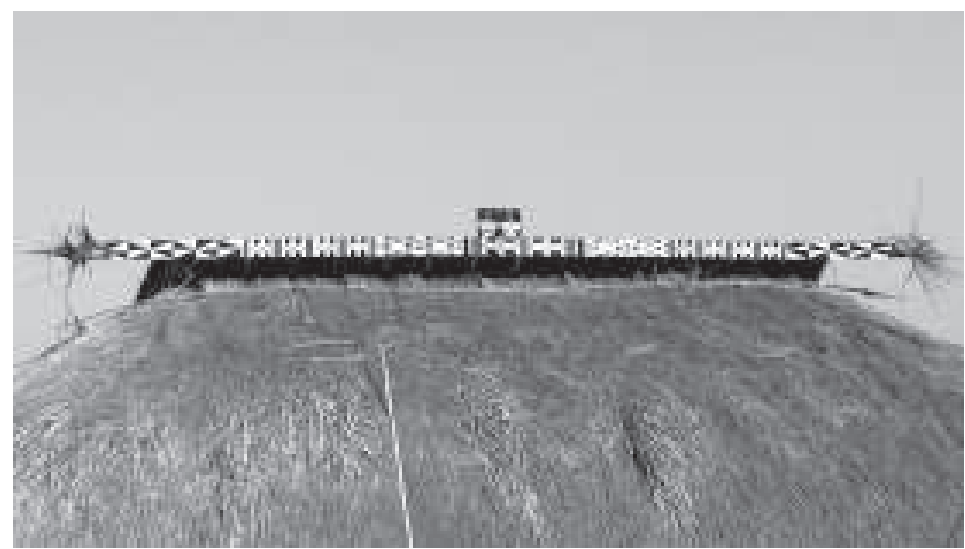

Figura 5: friso externo da casa dos homens, semelhante aos colocados na talïhe por fora (no teto) e por dentro (sobre as portas). Nas extremidades foi pintado um motivo bototo ijatagü ("axila de borboleta"); ao lado deles, outro motivo bototo ijatagï, a pintura da efígie masculina; em seguida, vem o motivo tüibitinbü, pintura corporal típica (também usada em efígies de mulheres). No centro, repete-se o padrão usado nas efígies masculinas. As duas plumárias no topo "representam" Taigi e Aulukumã, e as raízes nas extremidades são as "orelhas" ou "brincos" da casa.

Os pilares de sustentação da talïhe, seus mourões e os batentes das portas só podem ser feitos de $u^{1} / 2 g \ddot{g} h i$ - como já vimos, a mesma madeira da qual foram feitas as esposas de Enitsu1/2gü, e da qual são feitas as efígies mortuárias e o tahiti. Os dois pilares centrais recebem a mesma pintura das efígies masculinas, como se fossem efígies de quase 10 metros de altura. Talvez o elemento mais notável da decoração do interior dessa casa seja a presença de duas esculturas de barro ${ }^{26} \mathrm{com}$ formato de onça em frente à porta principal, uma de cada lado dos postes centrais. Já ouvi dizer que, idealmente, a da direita seria uma onça-pintada, e a da esquerda uma onça-parda (suçuarana); contudo a talïhe que havia em Aiha contava com duas onças-pintadas. Também já ouvi que, além das onças, pode-se fazer um veado no centro, ou apenas uma onça de um lado e um veado do outro, porque este é "comida para a

${ }^{26}$ Um barro vermelho que se obtém ao cavar o chão da casa a certa profundidade. 
onça". Heckenberger (2005, p. 258) nota que, para os Kuikuro, a escultura da direita seria uma onça, a da esquerda uma sucuri ou outro tipo de cobra, e, entre as duas, um sapo ("alimento para a anaconda", como o veado na talïhe kalapalo).

Essas esculturas servem para dizer aos que entram na talïhe que ela deve ser respeitada: são titsangitsoho, literalmente "que servem para provocar respeito". Respeito (itsangi) é o que se deve ter, de modo geral, por sujeitos classificados como Outros, principalmente os afins e os espíritos, marcando uma relação como potencialmente perigosa. Desrespeitar um afim provocaria extrema vergonha, e desrespeitar um espírito pode significar adoecimento ou morte. "Desrespeitar" significa se aproximar demais de uma figura de alteridade sem os devidos cuidados.

Um chefe kuikuro disse a Heckenberger que antigamente a talïhe era objeto de especial respeito por parte de seus afins, que nem sequer passavam perto dela ${ }^{27}$. O filho do último grande chefe nahukwa, que vive em Aiha, me disse que seu pai sempre viveu em talïhe, e que ele nunca construiu uma casa por iniciativa própria. Segundo ele, a casa de seu pai era "respeitada" porque ninguém entrava "sem nada nas mãos": quando iam até ela, as pessoas sempre levavam peixe, e às vezes pediam objetos, que seu pai nunca negava. De modo geral, os Kalapalo dizem que se deve tratar os chefes com "respeito", o que atualmente parece significar algo como "formalidade". Porém, aparentemente até não muito tempo atrás (antes da epidemia de sarampo de 1954, segundo o chefe mais velho), essa ideia de respeito era marcada pela afinidade, pois não se pronunciavam os nomes dos chefes, chamados apenas de tongisa ${ }^{28}$ - evocando a proibição de se pronunciarem os nomes dos afins. Assim, as figuras titsangitsoho parecem indicar que o dono daquela casa é alguém diferente e potencialmente perigoso, que deve ser tratado com cuidado e formalidade.

\footnotetext{
${ }^{27}$ Nas palavras deste chefe, “(...) os afins passavam longe dela, falavam mais suavemente, e a respeitavam com a máxima sacralidade [utmost sanctity]" (Heckenberger, 2005, p. 257).

${ }^{28}$ Vocativo para anetü. Nunca consegui uma tradução dessa palavra que não fosse "chefe". Ela ainda é usada nos discursos cerimoniais ligados à festa de trocas (uluki).
} 
Também há referências a serpentes na talühe, pois duas grandes sucuris são pintadas nas vigas que escoram o "peito" da casa (proteções contra vento). Penso que as serpentes podem estar ligadas ao ideal de que todo chefe deve ter sido um grande lutador. Para isso, é necessário incorporar substância-força de espíritos, pelo uso de "remédios" vegetais, que darão ao pretendente a "campeão" (ikindoto, "mestre da luta") força e habilidade. Um dos principais espíritos lutadores (e também chefe entre os peixes) é a Sucuri, cuja força de ataque é capaz de derrubar qualquer adversário. Para conseguir sua força, um lutador precisa cortar o rabo de uma sucuri viva, retirar sua carne, deixar a pele secar e usá-la para cobrir uma peça de madeira, de uns $90 \mathrm{~cm}$ de comprimento, cortada no formato de um rabo de cobra. Esse objeto se chama bibongo ("que fica sobre as costas"), e é usado como enfeite pelos homens quando tocam as flautas do Quarup (atanga). Antigamente, dizem, era usado apenas por grandes campeões, mas hoje imitações do enfeite original são usadas por qualquer homem. Esse objeto é “inalienável”, pois não pode ser dado nem vendido. Caso seu dono o dê ou troque, será agredido pelo espírito da Sucuri e ficará seriamente doente (um espírito escolhe dar força para um lutador por suas qualidades físicas e morais, e o desrespeito a essa escolha é perigoso).

Vê-se que a talühe é construída a partir da combinação de elementos associados ao mundo dos espíritos, tanto ao chefe das árvores (e à humanidade que ele evoca) quanto a espíritos de animais predadores (e à afinidade potencial à qual estão associados). Essa dualidade se replica, de forma um pouco diferente, no tahiti, que também está ligado, por seu material, ao chefe das árvores e à humanidade, mas, por sua forma, à condição ambígua de espíritoanimal e humano do chefe morto. Em uma aldeia onde todos se consideram parentes e partilham um mesmo "sangue" (objetivação substancial das relações de parentesco próximas), mora alguém ao mesmo tempo humano e não humano, consanguíneo e afim, condição que os alto-xinguanos têm necessidade de objetivar e tornar visível sob a forma de corpos-casas, sejam corpos humanos ou estruturas como o tahiti e a talïhe. 


\section{CHEFIA E PARENTESCO}

A objetivação dessa dualidade na chefia está no centro de movimentos de diferenciação e identificação por meio dos quais o parentesco xinguano é produzido. A relação dos chefes humanos com uma árvore especial (a $u^{1 / 2 g u ̈ h i) ~ d e v e-s e ~ a ~ u m a ~ c o n c e p c ̧ a ̃ o ~ v e g e t a l, ~ e ~ m a i s ~ p r e c i s a m e n t e ~ " a r b o ́ r e a ", ~}$ que os Kalapalo têm do parentesco e ao lugar ocupado nela pelos chefes. Os anetü são chamados de kuge ibü, ou ukugetibü, que significa "tronco-corpo das pessoas" (a palavra ibü designa tanto caules e troncos vegetais quanto o corpo humano). Tais "troncos-corpos", também chamados de "esteio de gente" (kuge iho), são o centro da vida coletiva, pessoas cujos cuidados e proteção são necessários para que as pessoas vivam juntas em uma aldeia por um longo período de tempo, e partilhem, pela convivência e comensalidade, um mesmo "sangue". Por serem pensados como responsáveis pela proteção, nutrição e alegria de seu povo, os chefes são tidos como "pais adotivos". No plano regional, as aldeias principais (maiores e que concentram as atividades rituais) também são consideradas iho de aldeias menores, evidenciando uma potencial organização assimétrica das identidades regionais. Essa imagem "vegetal" do parentesco também possui um aspecto temporal/geracional, no qual as raízes são vistas como os "avós", a base do tronco como os chefes principais, o tronco como os chefes menos importantes e os galhos como o povo em geral (ver Guerreiro Júnior, 2011c).

Essas ideias ficam explícitas no termo tisatipügü, pelo qual os Kalapalo falam ao mesmo tempo do parentesco consanguíneo e da chefia, e cuja raiz, ati, significa brotar ou crescer ${ }^{29}$. Tisatipügü tem dois sentidos: de um lado, quer dizer "nossos consanguíneos", e se refere aos parentes mais próximos, aqueles que "brotaram" juntos das mesmas "raízes" (que reconhecem relações genealógicas). De outro lado, tisatipügü significa "nossos chefes", e se refere tanto à continuidade genealógica entre os anetü (que "brotam" uns dos outros a cada geração) quanto à analogia entre chefes e troncos. "Os que cresceram conosco" são tanto "nossos parentes consanguíneos" quanto "nossos chefes",

${ }^{29}$ Aplicável somente ao crescimento vegetal. 
porque a (re)produção de troncos-chefes é parte essencial da produção do parentesco. Entre o passado (as raízes sob a terra) e o presente (os galhos da copa), estão os chefes, atuando como figuras de continuidade.

Contudo a produção dos chefes como "ancestrais" ou "pais adotivos" depende de sua apresentação ritual como predadores e inimigos para chefes estrangeiros. Um jovem geralmente só começa a ser reconhecido como anetü ao ocupar a posição de "chefe dos convidados" (ugihongo; lit. "que vai sobre o banco") em algum ritual patrocinado por outro povo. Nessas ocasiões, os chefes dos convidados e aqueles que foram convidá-los, "coordenadores" do ritual, são tidos como inimigos uns dos outros (imütongo, "que ficam face a face"). Ainda, encontros rituais são situações nas quais os chefes exibem insígnias de animais predadores, como coroas de couro de onça e colares feitos de suas garras, ou motivos gráficos associados à harpia, por exemplo. A etiqueta ritual os obriga a tratar-se com formalidade, como se vê nos gestos e discursos rituais que compõem os cumprimentos entre chefes estrangeiros, mas tais cuidados se devem justamente à posição recíproca de "predadores simbólicos" (e afins potenciais) ocupada por eles.

A necessidade dessa estética predatória deve-se à relação entre a capacidade de agressão e a capacidade de chefiar presente nas concepções kalapalo sobre as aldeias dos animais. Entre os animais terrestres, ninguém é um chefe maior do que a onça; entre os pássaros, essa posição é ocupada pela harpia, uma das maiores aves de rapina do mundo; e, entre os peixes, o peixe-cachorra desempenha essa função, com seus grandes dentes, seu tamanho avantajado e sua estética ameaçadora. Esses chefes dos animais fazem com que espécies diferentes partilhem uma vida coletiva e se vejam como semelhantes a despeito de suas diferenças - isto é, como parentes. Seres capazes de agredir são capazes de capturar outros em seu ponto de vista (Viveiros de Castro, 2002b), funcionando como polos de atração de diferenças (coletivização), assemelhamento corporal e, portanto, aparentamento.

Segundo Fausto (2008, p. 335), a capacidade predatória seria um princípio de englobamento: aquele que é capaz de comer alguém pode contêlo dentro de si. Contudo, é preciso notar que no Alto Xingu a capacidade predatória dos chefes precisa voltar-se para os outros, pois é na relação com 
outros coletivos que os chefes, tanto de animais quanto de humanos, são ativados. Muitos seres aquáticos, por exemplo, são chefiados por onças ou queixadas gigantes, que não são animais perigosos para os peixes, mas o são para os bumanos - para os quais aparecem quando estes realizam pescarias em grande escala. Entre os humanos, dá-se algo equivalente: os momentos de afirmação da condição de anetü, nos quais a diferença entre chefes e comuns é posta em relevo, são situações nas quais é preciso se confrontar com coletivos estrangeiros. Isso sugere que a lógica da "incorporação canibal”, como descrita por Fausto, nesse contexto precisa ser pensada em face de outras relações - não de consumo e englobamento, mas de confronto e diferenciação.

Em linhas gerais, a mito-história kalapalo narra um processo de diferenciação da humanidade, no qual os chefes ocupam um papel importante. No início, a humanidade era homogênea e indiferenciada, e a criação de identidades coletivas cada vez mais restritas - povos, aglomerados regionais, aldeias - foi o resultado de processos de fissão protagonizados por chefes. Todo processo de coletivização que fundamenta a vida coletiva e permite, pela convivência e pela comensalidade, a produção do parentesco, é viabilizado pelo antagonismo simbólico entre chefes. $\mathrm{O}$ único lugar onde a humanidade é homogênea, onde não há diferença nem afinidade, é a aldeia dos mortos chefiada pela mãe dos gêmeos. Lá, a chefia prescinde de seu lado predador, mas o preço a se pagar é a inércia que a caracteriza: mortos não se casam nem têm filhos. Para retomar a fabricação de pessoas nesse mundo, retomar a produção da vida, é preciso (re)produzir as diferenças que serão consumidas e reduzidas no processo do aparentamento (que, como sugiro, é um processo de diferenciação), e é a esse papel que serve a inimizade ritual dos chefes e os confrontos esportivos que marcam seus rituais. A assimetria interna a um grupo (consanguinidade fundamentada pela relação dos chefes com seu povo) é condicionada por relações de simetria externa (afinidade potencial entre chefes estrangeiros), fazendo da objetivação de tal dualidade condição do parentesco: aos estrangeiros, é preciso fazer-se ver como predador/inimigo; ao seu povo, como um ancestral, ou um "tronco-corpo".

Uma aproximação tentativa entre o material kalapalo e o conceito de Casa pode ser feita retomando as leituras de Lévi-Strauss (1986, p. 188-204) 
sobre materiais indonésios e melanésios. Nelas, o autor retém um aspecto que já fazia parte da definição original: a capacidade da Casa para transformar uma dualidade interna em uma unidade externa. Contudo, a Casa deixa de ser uma "instituição" (uma pessoa moral, como nas primeiras formulações), um "substrato objetivo" (Gordon, 1996, p. 192), para se tornar a objetificação, ou reificação, de uma relação. Lévi-Strauss argumenta que, na impossibilidade de recorrer aos critérios de filiação, propriedade ou residência na descrição de alguns grupos da Indonésia, "surge um critério que não fora percebido, o da aliança, já que os fatos atestam que, tanto em Bornéu como em Java, o casal conjugal forma o verdadeiro núcleo da família e, de modo mais geral, do parentesco" (Lévi-Strauss, 1986, p. 190). Nos casos indonésios, há uma diferença de status entre doadores e tomadores de esposas, com os primeiros ocupando uma posição superior. A arquitetura indonésia revelaria que a aliança aparece ao mesmo tempo como princípio de unidade e de antagonismo. Uma casa abriga diversas famílias ligadas por afinidade e, logo, com status diferentes, mas há um esforço para fazer com que, na disposição dos cômodos, essa diferença seja compensada: a família mais importante ocupa um dos lugares mais quentes da casa, para privar os demais desse desconforto; a família menos importante, por sua vez, ocupa o cômodo superior da casa, que é o menor, mas também o mais agradável. Segundo Lévi-Strauss, "acreditamos (...) que é preciso passar da ideia de um substrato objetivo para aquela da objetivação de uma relação: relação instável de aliança, que, enquanto instituição, a casa tem a função de imobilizar, ainda que sob uma forma fantástica" (Lévi-Strauss, 1986, p. 191).

O conceito se transforma de maneira ainda mais interessante quando o autor investiga se na Melanésia haveria formas institucionais do tipo "casa", que ele então define como aquelas

(...) que resultam do parentesco cognático, ou ainda do conflito entre dois modos concorrentes de descendência e, portanto, da necessidade de dar à ordem social um fundamento que não o genealógico, de escapar da realidade ou do mito dos "laços de sangue" em proveito da resistência 
ou desse ou daquele modo de determinação do status. (LéviStrauss, 1986, p. 198)

No caso da Nova Guiné, o próprio corpo bumano, tomado como um complexo andrógino capaz de evidenciar um ou outro aspecto em suas ações, ou como um composto de relações de consanguinidade e afinidade, capaz de evidenciá-las separadamente, aparece como um tipo de Casa:

Com efeito, por toda parte, trata-se de transcender um conflito entre duas preeminências, de mascarar o que as opõe e, se possivel, de confundi-las, com o risco de cindir, nos limites da "casa", os domínios com os quais seus constituintes se identificavam anteriormente. Crise social ao mesmo tempo inevitável, desejada e temida, da qual a Nova Guiné teria a originalidade de oferecer uma versão fisiológica, dando-lhe o corpo individual como cenário infinitamente multiplicado. (Lévi-Strauss, 1986, p. 204; grifos meus).

Há claros ecos entre essas definições e o material kalapalo. Porém devese fazer uma ressalva quanto ao atrelamento da noção de afinidade à aliança matrimonial de fato, que faz parte do argumento de Lévi-Strauss. Como comenta Michel Bergès (2008, p. 28), a Casa "permite imobilizar, hipostasiar, fetichizar sob uma forma fantasística as relações de aliança entre tomadores e doadores de mulheres". Fica claro que a afinidade em foco é a afinidade real. Contudo, na chefia kalapalo, a tensão entre consanguinidade e afinidade está vinculada aos papéis que esses dois tipos de relação desempenham na produção do ponto de vista dos humanos no mundo. A dualidade entre protetor/ predador, consanguíneo/afim é objetivada (e precisa sê-lo) nos corpos dos chefes, seja sob a forma do corpo individual, da residência nobre ou do túmulo-casa, pois a visibilidade de seu aspecto predador-inimigo pelos chefes estrangeiros, e de seu aspecto humano-ancestral por seus coaldeões, permite à chefia introduzir no interior da humanidade xinguana as diferenças a partir das quais se dão os processos de identificação e aparentamento. 
O corpo nobre explicita sua multiplicidade constitutiva ao mesmo tempo que a mascara na ficção de uma unidade complexa. É esse corpo que transmite nomes "bonitos" e "famosos" para corpos semelhantes, seus substitutos; é esse tipo de corpo-pessoa que pode ser dono de espaços, estruturas e conhecimentos restritos. E é esse tipo de corpo que permite a continuidade do processo do parentesco por meio da diferenciação de um grupo em relação a outros equivalentes e do aparentamento (assemelhação) de seus componentes. A chefia não é um "grupo" ao qual as pessoas possam pertencer, mas é uma condição fundada na síntese entre consanguinidade e afinidade, que se objetiva no corpo e se replica, torna-se visível, em diferentes escalas: uma Casa, mas em uma "versão fisiológica", tal qual o corpo-Casa melanésio analisado por Lévi-Strauss. Reunir questões de parentesco e política em sistemas não elementares de aliança é, desde as primeiras elaborações do conceito, uma das potências da Casa, e por isso tratar a multiplicidade de corpos da chefia xinguana a partir dele permite vê-los como algo mais que corpos.

\begin{abstract}
From time to time, the Kalapalo and other upper-xinguans build special structures to their chiefs: great decorated houses for living chiefs, and special graves for deceased nobles - also conceived as their "houses". This article analyzes how these structures hold a series of analogies with the body model of the chiefs, intending to show how noble houses, graves and bodies objectify, in different scales, a duality between humanity/consanguinity and animality/affinity. From a dialogue with Lévi-Strauss' formulations on the House, I argue that xinguan chieftainship is characterized by the synthesis of principles of unity and antagonism, whose objectivation is a necessary part of the movement by means of which the xinguan peoples differentiate and identify themselves in the regional system, providing the basis of the kinship process.
\end{abstract}

KEYWORDS: House, chieftaincy, kinship, Upper Xingu, Kalapalo. 


\section{REFERÊNCIAS BIBLIOGRÁFICAS}

AGOSTINHO, P. Kwarip - Mito e ritual no Alto Xingu. São Paulo: E.P.U/ EDUSP, 1974.

BARCELOS NETO, A. Festas para um "nobre”: ritual e (re)produção sociopolítica no Alto Xingu. Estudios Latino Americanos, v. 23, p. 63-90, 2003.

. Apapaatai: rituais de máscaras no Alto Xingu. São Paulo: EDUSP/ FAPESP, 2008.

BASSO, E. B. The Kalapalo Indians of Central Brazil. New York: Holt, Rimehart and Wineton Inc., 1973.

BERGÈS, M. Claude Lévi-Strauss et les réseaux: parenté et politique. KLESIS - Revne philosophique, n. 10, p. 1-33, 2008.

CARSTEN, J.; HUGH-JONES, S. (Eds.). About the House: Lévi-Strauss and Beyond. Cambridge: Cambridge University Pressed. 1995.

COELHO DE SOUZA, M. S. O traço e o círculo: o conceito de parentesco entre os Jê e seus antropológos. Rio de Janeiro, 2002. Tese de Doutorado, PPGAS - Museu Nacional, Universidade Federal do Rio de Janeiro.

Parentes de sangue: incesto, substância e relação no pensamento timbira. Mana, v. 10, n. 1, p. 25-60, 2004.

COELHO, V. P. Motivos Geométricos na Arte Uaurá. In: (Org.). Karl von den Steinen: um século de antropologia no Xingu. São Paulo: EDUSP, 1993, p. 591-629.

EMMERICH, M; EMMERICH, C.; VALLE, L. S. O Kuarupe - Árvore do Sol. Bradea - Boletim do Herbarium Bardeanum, IV (49): 388-391, 1987.

ERIKSON, P. Faces of the Past: Just How "Ancestral" Are Matis "Ancestor Spirit”" Masks? In: FAUSTO, C.; HECKENBERGER, M. J. (Eds.). Time and Memory in Indigenous Amazonia: Anthropological Perspectives. Gainesville: University of Florida Press, p. 219-242, 2007. 
FAUSTO, C. Donos demais: maestria e domínio na Amazônia. Mana, v. 14, n. 2, p. 329-366, 2008.

FIGUEIREDO, M. V. Centralização e faccionalismo: imagens da política no Alto Xingu. Rio de Janeiro, 2006. Dissertação de Mestrado, PPGAS - Museu Nacional/UFRJ.

A flecha do ciume. Oparentesco e seu avesso segundo os Aweti do Alto Xingu. Rio de Janeiro, 2010. Tese de Doutorado, PPGAS - Museu Nacional/ UFRJ.

GORDON, C. About the House: Lévi-Strauss and Beyond (Resenha). Mana, v. 2, n. 2, p. 192-195, 1996.

. Economia selvagem: ritual e mercadoria entre os Xikrin. Rio de Janeiro: UNESP/ISA/NuTI, 2006.

GOW, P. O parentesco como consciência humana: o caso dos piro. Mana, v. 3 , n. 2, p. 39-65, 1997.

GUERREIRO JÚNIOR, A. R. Assimetria e coletivização: notas sobre chefes e caraíbas na política Kalapalo (Alto Xingu, MT). In: COELHO DE SOUZA, M.; LIMA, E. C. D. (Eds.). Conbecimento e cultura: práticas de transformação no mundo indigena. Brasilia: A thalaia, 2010, p. 119-149.

Aliança, chefia e regionalismo no Alto Xingu. Journal de la Société des Américanistes, v. 97, n. 2, p. 99-133, 2011 a.

Esteio de gente: reflexões sobre assimetria e parentesco a partir de depoimentos de chefes kalapalo. R@U-Revista de Antropologia Social dos alunos do PPGAS-UFSCar, v. 3, n. 1, p. 95-126, 2011b.

Refazendo Corpos para os Mortos: As Efígies Mortuárias Kalapalo. Tipiti: Journal of the Society for the Anthropology of Lowland South America, v. 9, n. 1, Article 1, 2011c.

Ancestrais e suas sombras: uma etnografia da chefia kalapalo e seu ritual mortuário. Brasília, 2012. Tese de Doutorado - Departamento de Antropologia, Universidade de Brasília. 
HECKENBERGER, M. J. The Ecology of Power: Culture, Place, and Personhood in the Southern Amazon, A. D. 1000-2000. New York: Routledge, 2005.

. Forma do espaço, língua do corpo e história xinguana. In: FRANCHETTO, B. (Org.). Alto Xingu: uma sociedade multilingue. Rio de Janeiro: Museu do Índio - FUNAI, 2011, p. 235-279.

HUGH-JONES, S. Clear Descent or Ambiguous Houses? A Re-Examination of Tukanoan Social Organisation. L'Homme, v. 33, n. 126-128, p. 95-120, 1993.

Inside-out and back-to-front: the androgynous house in Northwest Amazonia. In: CARSTEN, J.; HUGH-JONES, S. (Eds.). About the House: Lévi-Strauss and Beyond. Cambridge: Cambridge University Press, 1995, p. 226-252.

LAMAISON, P.; LÉVI-STRAUSS, C. La notion de maison. Terrain: revue d'ethnologie de l'Europe, v. 9, 1987.

LEA, V. R. Nomes e nekrets Kayapó: uma concepção de riqueza. Rio de Janeiro, 1986. 587 p. Tese de Doutorado - Museu Nacional/UFRJ.

Casas e Casas Mebengokre (Jê). In: VIVEIROS DE CASTRO, E.; CARNEIRO DA CUNHA, M. (Orgs.). Amarônia: etnologia e bistória indigena. São Paulo: EDUSP, 1993, p. 265-282.

Casa-se do outro lado: um modelo simulado da aliança mebengokre (Je). In: VIVEIROS DE CASTRO, E. (Org.). Antropologia do parentesco: estudos amerindios. Rio de Janeiro: UFRJ, 1995a, p. 321-359.

The Houses of the Mebengokre (Kayapo) of Central Brazil: A New Door to their Social Organization. In: HUGH-JONES, S.; CARSTEN, J. (Eds.). About the House: Lévi-Strauss and Beyond. Cambridge: Cambridge University Press, 1995b, p. 206-225.

LÉVI-STRAUSS, C. Clã, linhagem, casa. In: . Minhas palavras. São Paulo: Brasiliense, 1986, p. 183-235. La voie des masques. Paris: Pocket, 2004. 
LIMA, T. S. Um peixe olhou para mim: o povo Yudjá e a perspectiva. São Paulo/Rio de Janeiro: ISA/ Unesp/NuTI, 2005.

RIVIÈRE, P. Houses, places and people: community and continuity in Guiana. In: CARSTEN, J.; HUGH-JONES, S. (Eds.). About the House: Lévi-Strauss and Beyond. Cambridge: Cambridge University Press, 1995, p. 189-205.

SAHLINS, M. Tribesmen. Oxford: Engelwood Cliffs, 1968.

SEEGER, A. The Meaning of Body Ornaments: A Suya Example. Ethnology, v. 14, n. 3, p. 211-224, 1975.

STRATHERN, M. One Man and Many Men. In: GODELIER, M.; STRATHERN, M. (Eds.). Big Men and Great Men: Personifications of Power in Melanesia. Cambridge: Cambridge University Press, 1991, p. 197-214.

VIVEIROS DE CASTRO, E. O problema da afinidade na Amazônia. In: _. A inconstância da alma selvagem. São Paulo: Cosac \& Naify, 2002a, p. $87-180$.

Perspectivismo e multinaturalismo na América indígena. In:

A inconstância da alma selvagem. São Paulo: Cosac \& Naify, 2002b, p. 345-399.

VON DEN STEINEN, K. Entre os aborigenes do Brasil Central. São Paulo: Departamento de Cultura, 1940.

WAGNER, R. The Fractal Person. In: GODELIER, M.; STRATHERN, M. (Eds.). Big Men and Great Men: Personifications of Power in Melanesia. Cambridge: Cambridge University Press, p. 159-173, 1991. 